\title{
NICOLAI HARTMANN ON THE VALUE OF AESTHETIC EXPERIENCE
}

\section{SAULIUS GENIUSAS}

PhD in Philosophy, Associate Professor.

Chinese University of Hong Kong, Department of Philosophy.

Hong Kong, SAR.

E-mail: geniusas@cuhk.edu.hk

I argue that Hartmann's engagement in the question of the value of aesthetic experience (especially as addressed in Chapter 35 of his Aesthetics) is a specific reinterpretation of the standpoint that we come across in Nietzsche's Birth of Tragedy. Hartmann completed his Aesthetics at the end of World War II and some of the central claims in his work echo Nietzsche's standpoint, as presented in the early work on tragedy, which Nietzsche completed during the Franco-Prussian war. Both studies invite us to ask: what are we to expect from philosophy under such circumstances? Like Nietzsche, Hartmann holds the view that 1) our lives are intrinsically meaningless, that 2) the world is indifferent to meaning, and that 3) aesthetic experience has value insofar as it bestows meaning both on the world and on human existence. Despite the far-reaching thematic and stylistic differences between Hartmann and Nietzsche, both thinkers see aesthetics not as a form of apolitical escapism, but as a direct way of confronting the fundamental problem, which concerns "the sense and meaning of the world and of human life." They both leave us with the paradoxical and provocative thesis that aesthetic experience is exactly what is needed at the times of political crises.

Key words: Aesthetic experience, aesthetic values, aesthetic qualities, aesthetic creativity, aesthetic meaningfulness, Hartmann, Nietzsche.

\section{НИКОЛАЙ ГАРТМАН О ЦЕННОСТЯХ ЭСТЕТИЧЕСКОГО ОПЫТА}

\section{САУЛЮС ГЕНЮШАС}

Доктор философии, профессор.

Китайский университет Гонконга, Департамент философии.

Гонконг, САЦ.

E-mail: geniusas@cuhk.edu.hk

Я утверждаю, что вклад Гартмана в обсуждение вопроса о ценности эстетического опыта (особенно в том виде, в каком он рассматривается в гл. 35 его Эстетики) - это специфическое переосмысление точки зрения, с которой мы сталкиваемся в Рождении трагедии Ницше. Гарт-

(C) SAULIUS GENIUSAS, 2019 
ман завершил свою Эстетику в конце Второй Мировой Войны, и некоторые из центральных утверждений в его работе перекликаются с точкой зрения Ницше, представленной в ранней работе о трагедии, которую Ницше завершил во время франко-прусской войны. Оба исследования приглашают нас спросить: чего мы должны ожидать от философии в таких обстоятельствах? Как и Ницше, Гартман придерживается мнения, что 1) наша жизнь изначально бессмысленна; 2) мир безразличен к смыслу; 3) эстетический опыт имеет ценность, поскольку он придает смысл как миру, так и человеческому существованию. Несмотря на значительные тематические и стилистические различия, оба мыслителя рассматривают эстетику не как форму аполитичного эскапизма, а как прямой способ решения фундаментальных проблем, касающихся «смысла и значения мира и человеческой жизни». Оба мыслителя оставляют нас с парадоксальным и провокационным тезисом о том, что эстетический опыт - это именно то, что нужно в эпоху политического кризиса.

Ключевые слова: Эстетический опыт, эстетические ценности, эстетические качества, эстетическое творчество, эстетическая осмысленность, Гартман, Ницше.

Nicolai Hartmann completed the first sketch of his Aesthetics in the summer of 1945 in Babelsberg near Potsdam. As Frida Hartmann notes in the Postscript that she wrote to her husband's Aesthetics in June 1953

he began the manuscript of the $9^{\text {th }}$ of March, and completed it on the $11^{\text {th }}$ of September. This was the time of the destruction of Potsdam, the encirclement and conquest of Berlin, and, in general, of hunger, uncertainty and confusion [...]. In the midst of this collapse he wrote his pages, day by day ${ }^{1}$. (Hartmann, 2014)

The first years after the war were filled with too many other concerns and therefore, Hartmann could not start revising the manuscript as was his lifelong practice with other works he had written before. He started working on the new manuscript five years later, in 1950, and he passed away before the revisions were complete. The revised manuscript "breaks off with the words, 'Ideas in Poetry', the heading on page 196 [...] From page 196 to the end, this edition follows the first manuscript," which Hartmann was working on in 1945, in "complete severance from the outside world."

Hartmann's Aesthetics offers a remarkably detailed and sober analysis of some central issues in the field, and especially the way it was conceptualized in the first half of the twentieth century. It addresses beauty in all its generality: in nature as well as in diverse forms of art (painting, music, architecture, and ornamentation); it pursues a lucid analysis of the structure of aesthetic experience, taken both in terms of its receptivity and creativity; it offers a somber analysis of aesthetic values. Yet keeping in mind the circumstances under which it was composed, one cannot help but be surprised:

1 As Eugene Kelly mentioned to me in a recent conversation, Hartmann wrote this work not 'day by day', but night by night, when his children were asleep and nobody in the house would disturb him. 
What sense are we to make of a detailed study of all these themes undertaken in the final months, weeks and days of the war?

I do not wish to offer a historically-oriented analysis of Hartmann's life at this historical moment. The question that I wish to address is more philosophical: what should one expect from philosophy under such circumstances? Does philosophy have the right to turn to such seemingly apolitical themes under such conditions? Does a philosopher not compromise the significance of his own philosophy by turning to such 'safe themes' under such disturbing circumstances ${ }^{2}$ ? Let us not forget that Hartmann, who in the first half of the twentieth century was considered to be one of the central figures in German philosophy, was almost entirely forgotten in the second half of the twentieth century and remains largely forgotten to this very day. Does this forgetfulness not derive from his silence about the 'burning questions' of the day? The situation is highly ironic, for those German philosophers who were quite actively involved in the fascist movement in Germany before the war, retained their influence worldwide after the war for the reasons that, presumably, their reflections had something to contribute to our understanding of the human condition in general, and political situation in particular. By contrast, Hartmann, who never compromised with Nazism, remains a largely forgotten figure.

Hartmann's political silence can be interpreted at least in four ways. First, one could see it as a straightforward form of escapism. Is there any other field that could provide one with a better possibility to withdraw than aesthetics? Secondly, one could also argue that it is motivated by philosophical commitment and dedication, to which one could further add that external pressures not so rarely create a sense of contrast which can prove to be highly conducive to intellectual work. Thirdly, one could also maintain that, appearances to the contrary notwithstanding, Hartmann's aesthetics is an indirect way of dealing with the circumstances at hand. Fourthly, one cannot discount the possibility that we face here a mixture of the three elements just mentioned. I am especially intrigued by the third possibility and in what follows, I will try to provide some reasons to defend such an interpretation.

Despite all the inner serenity and intellectual commitment from the outside world that the composition of such a work must have called for, Hartmann appears to have been well aware that his situation was neither unique, nor unprecedented. The historical and political circumstances that surround the composition of his Aesthetics

2 Let me note in passing that Hartmann is certainly not the only intellectual to have addressed seemingly distant themes during World War II. At the same time, in St Petersburg, Olga Mikhailovna Freidenberg was working on her famous study of mythology while Maria Yefimovna Sergeyenko on the no-less famous study of agriculture in the Roman Empire. 
are very much the same as those under which Friedrich Nietzsche composed his Birth of Tragedy. Nietzsche wrote this work during the Franco-Prussian war of 1870-1871. In the "Attempt at a Self-Criticism," which he republished along with the Birth of Trag$e d y$ in 1886, Nietzsche writes:

While the thunderclap of the Battle of Wörth was reverberating across Europe, the meditative lover of enigmas whose lot it was to father this book sat somewhere in a corner of the Alps, extremely reflective and perplexed (thus simultaneously very distressed and carefree) and wrote down his thoughts [...]. A few weeks after that, he found himself under the walls of Metz [...] in that month of the deepest tension, as peace was being negotiated in Versailles, he finally came to peace with himself and [...] finished composing the Birth of Tragedy out of the Spirit of Music. (Nietzsche, 2000, 17)

Besides the circumstances under which both works were composed, is there anything else that they share? The styles in which they are written, the thoughts they articulate, and the contributions they make are fundamentally unlike each other. Moreover, Hartmann's Aesthetics is his mature work, whose revisions were interrupted by the author's death. By contrast, The Birth of Tragedy is Nietzsche's first book, "also in every bad sense of that label" (Nietzsche, 2000, 19), as Nietzsche was to add in 1886.

The far-reaching differences between these works should not overshadow one fundamental affinity between them-an affinity that directly relates to the circumstances under which these two masterpieces in aesthetics were composed. The way in which Hartmann confronts the question of the meaning of aesthetic experience (especially as address in Chapter 35 of his Aesthetics), that is, the way he raises the question of the value of aesthetic values is Nietzschean through and through. I would venture to suggest that Hartmann's engagement in this question is a specific reinterpretation of the standpoint we come across in Nietzsche's Birth of Tragedy; I can only conjecture that this reinterpretation must have been triggered by Hartmann's explicit awareness of the similar circumstances that underlie the composition of both works.

How are we to understand the question here formulated in a heavily Nietzschean way, namely, the question of the value of aesthetic values? This question concerns the existential significance of aesthetic experience in general, and of art, in particular. This issue calls for some clarification.

First, one should stress that neither Hartmann nor Nietzsche employs the concept of aesthetic experience. In the present context, this heavily over-determined term is meant to identify the kind of experience through which aesthetic values are given. Aesthetic experience differs from other types of experience in that it intends aesthetic values. We can intend different types of phenomena-theoretical, practical, aesthet- 
ic-only because we are capable of different types of experience. Such aesthetic values as beauty, the sublime, the graceful, the charming, the pleasing, the moving, the idyllic, the comical, the humorous and the tragic fundamentally rely upon our capacity to experience the world aesthetically.

What, then, is the value of aesthetic experience? In The Birth of Tragedy, Nietzsche argued that the function of aesthetic experience (conceived as that experience, which can access aesthetic phenomena) is none other than that of making life liveable. "It is only as an aesthetic phenomenon that existence and the world are eternally justified" (Nietzsche, 2000, 52)—so runs Nietzsche's most famous, mysterious, provocative and significant pronouncement that he formulates in his early work ${ }^{3}$. Hartmann's answer to this very same question runs along the same lines, although, admittedly, it is more restrained: "basically, all experience of beauty (the state of being aesthetically valuable) has philosophical significance just because it bestows meaning upon our lives. For without our seeing a meaning in our lives over the course of it, we could not live" (Hartmann, 2014, 442).

Like Nietzsche, Hartmann is committed to the view that our lives are intrinsically meaningless. So also, like Nietzsche, Hartmann is committed to the seemingly anti-metaphysical view that the only meaning our lives might have is the meaning we ourselves project upon it. Furthermore, like Nietzsche, Hartmann holds the view that what makes aesthetic experience valuable is the meaning-generating function that it performs. However, unlike the early Nietzsche (although, one might add, in line with Nietzsche's thoughts in his more mature writings), Hartmann holds the view that aesthetic experience is one of the resources from which life can obtain its meaning and significance.

In the concluding pages of Hartmann's Aesthetics, we witness the reappearance of some "inexpungible metaphysical problems," among which, "one of the oldest and most peremptory is that of the sense and meaning of the world and of human life" (Hartmann, 2014, 438). Insofar as one's life is guided by a belief in a higher power, this question does not arise: it is answered from the start. Yet especially under the circumstances that surround the composition of this work, it is terribly hard to retain such a belief: for the author of this work, hiding from the outside world not far from Berlin, during the final months, weeks, and days of the war, everything must have spoken against it. Hartmann's following remarks should not surprise us: “...if faith collapses, then the problems, arising as though out of nothingness, are suddenly there. And then

3 In The Birth of Tragedy, Nietzsche repeats this dictum on two other occasions. See Nietzsche (2000, $22,141)$. 
they may straightaway become life threatening. For who would want to live a life that has no sense?" (Hartmann, 2014, 438).

Like Nietzsche, Hartmann asserts that the question concerning the sense and meaning of the world and of human life has always been provided with one and the same answer, which both identify as metaphysical, in general, and Platonic, in particular. Hartmann maintains that this answer has always tacitly relied upon two principles: presumably, a) meaning can only lie at the origins of things; it cannot emerge in the world in the course of its history; b) so also, meaning can only inhere in the whole of the world; it cannot emerge from a part, or pass from a part to the whole (Hartmann, 2014, 439). Yet the world experience that underlies the composition of Hartmann's Aesthetics is such that it becomes impossible to hold on to the view that the sense and meaning covers the world and human life in their entirety, either in terms vertical depth and horizontal breadth. Small wonder, then, that Hartmann would assert that both assumptions have proved to be unjustified prejudices. In Hartmann, much like in Nietzsche, such a response is not presented in a form of a worked-out argument, but just in the form of a descriptive statement: it relies, one could say, on phenomenological rather than on logical self-evidence.

"What then remains? A world devoid of sense? In such a world man cannot live, at least not in full awareness of its senselessness" (Hartmann, 2014, 439). We cannot help but must consider alternatives. With this in mind, let us reverse the two assumptions, which have lost their hold on us: they no longer appear either as self-evident affirmations or as sound inferences that we draw from some other self-evident affirmations. Can we conceive of a meaning that does not lie at the origin of things but flows into the world post factum? Can we conceive of a meaning that originates not in the whole, but in a part, and that passes from a part to a whole? Hartmann answers both questions affirmatively. One could argue that despite his resistance to all metaphysical approaches to the question at hand, Hartmann's answer relies on a certain metaphysics, namely, on the view that the world is neither inherently meaningful, nor is it hostile to meaning. Avoiding both extremes, Hartmann contends that the world is just indifferent to meaning ${ }^{4}$. Building his case on such a metaphysical basis, Hartmann maintains that a human being can find himself in a meaningful world if, and only if, he himself bestows meaning upon the world. By itself, this does not mean that, as

4 In this regard, one could argue that Hartmann is more consistent than the early Nietzsche, who is all too quick to reinterpret the world's indifference to meaning as the world's hostility to meaning. This becomes especially noticeable in the so-called wisdom of Silenus, which Nietzsche accepts as representative of the tragic wisdom of the Greeks: "what is best of all is [...] not to be born, not to be, to be nothing. But the second best for you is-to die soon" (Nietzsche, 2000, 42). 
Nietzsche has it, "the existence of the world is justified only as an aesthetic phenomenon" (Nietzsche, 2000, 22). Rather, "every morally good act, every wise thought, every adequate response to a value, is meaningful and bestows additional meaning just out of itself alone" (Hartmann, 2014, 439). Thus, the sense and meaning of the world and of human life draws its sustenance from human acts, for it is these acts alone that can provide both with meaning, if they are to have any meaning at all. Only a world that is indifferent to meaning can become meaningful. We could describe Hartmann's standpoint as an anti-Platonic metaphysics that clarifies how an intrinsically meaningless world can become meaningful.

Hartmann, much like Nietzsche before him, maintains that the only meaning that the world and human life might have will be the meaning that we ourselves will bestow on in. Presumably, such an act of sense-bestowal is the subjective origin that renders life liveable. However, in contrast to Nietzsche, Hartman does not contend that only by bestowing meaning on life aesthetically can we render life liveable. What we have said so far does not tell us anything about aesthetic values or the concrete way in which they can bestow meaning on life.

Hartmann considers it to be an obvious fact that all meaning in the world is connected to values, be they moral, practical, or aesthetic. With this in the back of our minds, we can ask: is there anything specific about the bestowal of meaning upon the world and human life that derives specifically from aesthetic values? Following Kant, Hartmann holds the view that the aesthetic attitude is essentially disinterested and non-practical. Hartmann takes this to mean that when we relate to the world aesthetically, we see it as infused with intrinsic, and not just instrumental, value. I would contend that a being that recognizes surrounding things as intrinsically meaningful cannot help but must consider life liveable. To find oneself in the world that is soaked in aesthetic values is to have the "convincing feeling of standing face to face before something of absolutely intrinsic value-before something for whose sake alone it would be worth living, regardless of how the conditions of one's life stand otherwise" (Hartmann, 2014, 440) and despite all the "compromises, half-measures and distress" (Hartmann, 2014, 442) that otherwise, life affords.

There are things in life more likely to occur the more one tries to avoid them. So also, there are things in life less likely to occur the more one tries to realize them. So argued Max Scheler in his Vom Sinn des Leidens (Scheler, 1992, 106), suggesting that pain and suffering exemplify the first group of things, while joy and happiness fall into the second category. When Hartmann speaks of "Scheler's law" in his Aesthetics (Hartmann, 2014,364 ), he has this very structure of experience in mind. Thus, echoing Scheler's view, Hartmann writes: "happiness can be striven after, but cannot be realized in striving. 
Whoever strives for happiness destroys his chances for it almost necessarily" (Hartmann, 2014, 366). I would suggest that this very structure of experience underlies Hartmann's own solution to the problem he identifies as the problem of "the sense and meaning of the world and of human life" (Hartmann, 2014, 438). The more we seek this sense and meaning, the more it withdraws. It can be secured only behind one's back. One way to secure it is to turn to aesthetic values, discover them in the world of things around us.

Let us recapitulate Hartmann's argument. Insofar as we are capable of seeing the world as infused with aesthetic values, we are capable of seeing it as intrinsically valuable. Insofar as we are capable of seeing it as intrinsically valuable, we render the world both liveable and meaningful. The capacity that we, humans, have to recognize aesthetic qualities in things around us is exactly what enables meaning to "penetrate the darkness of suffering and distress" by "entering those places where other powers have lost their strength to succour us" (Hartmann, 2014, 442). Thus, much like Nietzsche before him, Hartmann also appears to suggest that his preoccupation with aesthetics during the war years is not a matter of apolitical escapism, but quite on the contrary, it is a direct way of confronting the fundamental problem the world faced at the time and, one might add, the very same problem it continues to face, namely, the problem of 'the sense and meaning of the world and of human life.' According to Hartmann's paradoxical and provocative thesis, despite all the physical, moral and spiritual destruction, the human capacity to undergo aesthetic experiences remains one of the fundamental ways in which this problem can be resolved.

What sense are we to make of the argument just offered? According to Hartmann, one of the things that makes life liveable is our capacity to see the world filled with aesthetic qualities and values. Yet does this argument not beg the question? We need to raise the basic question and problematize a seemingly obvious assumption: is it really true that we can see the world as beautiful, that is, to see it soaked in aesthetic qualities? The answer is by no means self-evident. For a view contrary to Hartmann's, it suffices to recall Jean-Paul Sartre's conclusion to his The Imaginary:

The real is never beautiful. Beauty is a value that can only ever be applied to the imaginary and that carries the nihilation of the world in its essential structure [...]. To say that one 'takes' an aesthetic attitude to life is to confuse the real and the imaginary [...]. The extreme beauty of a woman kills the desire for her [...]. In order to desire her it is necessary to forget that she is beautiful, since desire is a plunge into the heart of existence, into what is most contingent and most absurd. (Sartre, 2004, 193-194)

A detailed analysis of Sartre's early view on art would take us too far astray. In the present context, I only wish to stress that, according to Sartre, such aesthetic 
categories as beauty have no place in the horizon of actuality. With Sartre's position in the back of our minds, we have to ask: when Hartmann asserts that we are capable of seeing the world as aesthetically valuable, does he not conflate consciousness of irreality with consciousness of reality, although they plainly are two distinct modes of intentionality?

The answer is a definite No. Hartmann is in full agreement with Sartre as far as the insight into the derealizing function of aesthetic experience is concerned (more on that later). However, while accepting Sartre's premises, Hartmann is nonetheless led to fundamentally different conclusions, namely, to the view that human life can bestow aesthetic qualities upon our actual world experience. Here we touch upon a highly interesting thought in Hartmann, which was subsequently to be developed further, especially in the works of Paul Ricoeur ${ }^{5}$. In full agreement with Sartre, Hartmann writes: "the aesthetic object is lifted out of the daily bustle, out of the obligations in life that weigh upon us, out of all of permanent features of the everyday" (Hartmann, $2014,442)$. Yet he continues this thought in a decidedly anti-Sartrean fashion:

...the reverse manifests itself: the re-entry into our life of what had been lifted out of it - but not to assimilate itself to it, and thereby vanish, but rather to give to life what is for its needs of the greatest importance: meaningfulness. Perhaps one should put it more cautiously: it is the knowing or beholding of a meaning-content. (Hartmann, 2014, 442)

We can take this to mean that, according to Hartmann, the aesthetic experience one undergoes is a derealizing experience that unfolds in the field, which Sartre identifies as irreality. Nonetheless, what one experiences in this field can be re-transcribed into the field of actuality. Aesthetic experience can re-enter the domain of actual experience by lending it what it otherwise lacks, namely, meaningfulness. It re-enters the field of actual experience not by transforming the things we encounter around us, but transfiguring their manners of appearance. As far as we are dealing only with aesthetic experience, we can further say that we are dealing with intrinsic meaningfulness exclusively: with values which, as Hartmann puts it, 'burden us with nothing' and 'demand and foster nothing': they are gifts, and nothing more than gifts, which call for us to behold them and take part in the 'pure joy' they offer us.

In philosophical literature of the second half of the twentieth century, and especially in French philosophy, we come across quite extensive literature on givenness in general, and gifts, in particular. The analysis of this theme has always served one and the same purpose, namely, that of demonstrating that subjectivity cannot be

5 Here I am referring to Paul Ricoeur's essays on productive imagination, including his unpublished lectures on the imagination, which he delivered at the University of Chicago in 1975. 
conceived as the transcendental origin meaning. In this regard, Hartmann's scattered reflections on gift giving are highly refreshing. His analysis does not suggest that the problematic of the gift somehow requires that we speak of the death of the subject in more or less explicit ways. Quite on the contrary, giving of gifts "takes two, and there is something the recipient must supply: the taking" (Hartmann, 2014, 442-443). In short, in a desubjectivized world, there can be no gifts and no gift giving.

Aesthetic experience is a peculiar way of experiencing, which is not to be confused with natural experience. To see the world as beautiful, we first and foremost need to "learn to see" (Hartmann, 2014, 281). Here we touch upon the indissoluble interrelation of mimesis and poesis, of imitation and creativity, which Hartmann conceptualizes as a subjective interplay of forces that underlie art creation (Hartmann, 2014, Ch. 20). It is interesting to note that the example Hartmann uses to illustrate the artistic effects of such an interrelation is the very same example that Paul Ricoeur will employ in his Lectures on the Imagination, while speaking of the power of productive imagination. "It is true that the painter-and yet not before his art reached a certain level of development-was the first to discover 'the landscape' and thereupon also taught the layman to see nature for himself" (Hartmann, 2014, 281). We can take this to mean that, according to Hartmann, there is nothing natural about our capacity to see the world as beautiful, presuming that we have such a capacity. It's a learned capacity; but if so, then we can further add, that this capacity can also be forgotten.

Let us recapitulate the path we have taken so far. The world can be meaningful if, and only if, human life bestows meaning upon it. To bestow meaning upon the world is to bestow upon it certain values. One way to do so is to bestow upon the world aesthetic values. This can be done by means of learning how to see, that is, by means of re-transcribing the aesthetic experience we undergo in the domain of irreality into the domain of actuality.

But when so much is said, further problems open up. We now realize that the bestowal of meaning upon human life and the world itself rests upon a more primitive bestowal, namely, the bestowal of values upon the aesthetic object, which originally, can only be given in the domain of irreality. From the question concerning our presumed capacity to see the world as infused with aesthetic values we are led back to the question concerning the bestowal of values in the arts.

Let us briefly trace Hartmann's analysis of this issue, which he presents under the heading of the bestowing of forms in the arts (Hartmann, 2014, Ch. 17). Hartmann's analysis is guided by the insight that aesthetic creativity entails the elements of selection, omission and supplementation. Thus, the artist never simply imitates the surrounding nature. At least as far as representational artworks are concerned, the 
artist selects certain aspects at the expense of others; s/he thus omits other aspects as unworthy of representation; so also, s/he supplements in the artwork itself what nature itself does not offer. In short, the process of the creation of the artwork is always already a fusion of mimesis and poesis, of imitation and creativity. Such an interplay of selection, omission and supplementation gives rise to the idea that the artist conceives aesthetically and wishes to actualize as an aesthetic object.

Building on such a basis, Hartmann singles out three moments that make up the structure of aesthetic creativity. First, aesthetic creativity brings about a transformation in the structure of the human psychic elements and their presentation in non-psychic and non-human medium. By this we are to understand that, according to Hartmann, something alive is shaped in lifeless matter, be it in words, colours, or stone. We face here the objectivation of what initially appears within the boundaries of inwardness-a mere insight, or a preliminary form, which in the initial stage of aesthetic creativity is not yet materialized. Its materialization, or as Hartmann has it, its objectivation constitutes the first element of artistic creativity.

Second, we can further qualify the objectivation of which we here speak as the aesthetic object's transformation into something unreal. By this we are to understand that when the artist shapes something, that is, when the artist transforms the initial idea into a material substance, $s /$ he does not actualize the object of intuition, but only offers its representation. Thus "the figures that the poet creates are not made real by him, any more than the things that the painter shows us: they all remain unreal, and make no pretence to reality" (Hartmann, 2014, 246). Otherwise put, the artistic objectivation is nothing other than the object's derealisation: as far as aesthetic perception is concerned, the material object loses its reality by obtaining its aesthetic phenomenality. Thus, looking at a painting as a painting, we no longer see the canvas, but only the representation; when we hear a musical work, we no longer hear sounds, but rather tones and melodies; last but not least, when we are enraptured by a novel, we do not see pieces of paper bound to each other, but are absorbed in the meaning of the novel, etc.

Thirdly, such an objectivation of what originally was only a psychic element, an objectivation, which at the same time marked the material object's derealization, is a transformation that results in the aesthetic object's greater intuitive clarity. By this we are to understand that insofar as the insight that underlies aesthetic creativity is given in its original purely psychic form, it remains largely incomplete, incoherent, and imprecise, and that it gains completeness, coherence and precision only in the process of its artistic development. "The poet, the painter, the sculptor, yes, even the musician, each lifts these objects out of their shadowy vagueness and makes them 'indirectly' 
visible, audible, imaginable" (Hartmann, 2014, 246). Thus, the connection of reality and clarity that we normally assume in life loses its validity when we are confronted with aesthetic intuitivity and aesthetic clarity. The latter two are to be understood as 'intuitability of a higher order,' which is identical with 'second seeing' or 'beholding' that is attached to perception as a founded stratum, which relies upon perception, although cannot be reduced to perception.

At this point, we are in the position to understand Hartmann's contention that aesthetic experience relies upon the human capacity 'to learn how to see.' No matter how paradoxical it might sound, perceiving an artwork as an artwork relies upon us having learned how to perceive it. The processes of selection, omission and supplementation that underlie the creation of artworks provide us with sufficient proof that aesthetic seeing is irreducible to natural seeing. Even in the case of representational art, when we see an aesthetic object, we recognize the moments of selection, omission and supplementation, that is, we recognize that an artwork is a unity of mimesis and poeisis, and only as such can it give rise to aesthetic appreciation. An artwork, conceived as an embodied form that provides both the artist and the audience with increased intuitive clarity, can be seen and appreciated only insofar as we learn how to see it and appreciate it.

How, then, is it possible to for us to recognize aesthetic qualities not only in artworks, but also in the world that surrounds us? That is, how can aesthetic values re-enter our lives after being lifted out of it, although not to assimilate with objects around us, and thus vanish, but rather "to give life what is for its needs of the greatest importance: meaningfulness?” (Hartmann, 2014, 442) I would suggest that such a re-entry relies upon two conditions: 1) aesthetic values cannot be reified; no one has the power to transform them into things among things. Here we are not discussing any real change in things. Rather, aesthetic values can be experienced only phenomenally, only as qualities that affect appearances of things. 2) The manner in which the actual world appears to us can be permeated with aesthetic qualities if, and only if, one learns how to see, and this learning to see relies upon the processes of selection, omission and supplementation. Otherwise put, the infusion of the world with aesthetic values relies upon a creative interplay of perception and aesthetic fantasy, which in their unison provide us with a sense that we see actual objects around us, while nonetheless modifying their manners of appearance by supplementing them with aesthetic qualities. The aesthetic way of bestowing meaning on life relies upon such a creative interplay of these two forces. Recall Hartmann's intriguing contention that "without our seeing a meaning in our lives over the course of it, we could not live" (Hartmann, 2014,442 ). At this point we can say that the meaning in question does not rely upon 
a real change in things, but only upon a subjective reorientation: "nothing is removed, yet a spiritual good is bestowed" (Hartmann, 2014, 442). It is our learning how to see that renders such a subjective reorientation possible.

In his introduction to Hartmann's Aesthetics, Eugene Kelly remarks:

...if Hartmann is generally unread today, that may be due to the fact that he speaks out of a tradition of art that has been successfully deconstructed, and new forms of art have liberated themselves from older traditions and created our not always brave new world. (Hartmann, 2014, xxxii)

This estimation is largely correct: no matter how sympathetic one might be to Hartmann's works, it is by no means easy to see how the concepts he employs and the phenomena he describes in his Aesthetics could be helpfully employed in the analysis of contemporary art, which pays such a strong emphasis on incoherence and randomness. Of course, we can say the same about most of the modern classical theories in aesthetics, from Hume and Kant onwards. It appears to be undeniable that much of contemporary art is a rebellion against these very theories. However, such a critical assessment, even if it is accepted, does not mean that Hartmann's aesthetics is just as powerless in the face of classical traditions.

In the place of conclusion, I want to return to the circumstances under which Hartmann's Aesthetics was written. What sense are we to make of Hartmann's decision to write a work on aesthetics during the months that were to decide the world's history? Moreover, what sense are we to make of all the resilience, serenity and dedication that the completion of this voluminous study must have called for? Needless to say, we do not encounter any references to the actual state of affairs in Hartmann's Aesthetics. Are we, then, to conclude that this work is a straightforward expression of philosophical escapism, and thus of philosophy's own irrelevance in the course of world's history?

Should one consider such a view to be too dismissive, one would have to look for ways to justify Hartmann's silence and indifference. Here I tried to offer one possible clarification of this matter, a clarification that focuses on Hartmann's reflections on what could possible make human life meaningful and liveable. The question that is posed here is the very same that we come across not only in Nietzsche's Birth of Tragedy, but also in Jean-Paul Sartre's famous lecture, "Existentialism is a Humanism," which was delivered just a month after Hartmann completed his original manuscript. Let us not forget that Sartre was recognized as one of the main philosophers of the post war years precisely due to the popularity of this lecture, which was received almost as a manifesto that spelled out the new philosophical principles in accordance 
with which post war Europe was to be rebuilt. I wish to stress that Sartre's central point in this lecture is the very same that we come across in Hartmann's Aesthetics, and the very same that I focused on above: if human life is to have meaning, this meaning will derive from human life itself. A significant difference between Sartre and Hartmann on this issue concerns Hartmann's contention that aesthetic experience is one of the fundamental sources from which human life can draw its sustenance. In "Existentialism is a Humanism," Sartre does not explore such a possibility. With this in mind, let me conclude by saying that Hartmann's Aesthetics is a living testimony to the fact that philosophical engagements in 'the problems of the day' do not always, and should not always, take direct form. Precisely because philosophy is not politics, it must create its own ways to confront the problems we face.

\section{ACKNOWLEDGEMENTS}

This paper was delivered at the Nicolai Hartmann International Conference, which was held at Saint-Petersburg State University in December, 2017. I am grateful to the participants for their comments.

\section{REFERENCES}

Hartmann, N. (2014). Aesthetics. Berlin, Boston: de Gruyter.

Nietzsche, F. (2000). The Birth of Tragedy. Oxford: Oxford University Press.

Sartre, J.P. (2004). The Imaginary: A Phenomenological Psychology of the Imagination. London, New York: Routledge.

Scheler, M.(1992). The Meaning of Suffering. In M.Scheler, On Feeling, Knowing, and Valuing (82115). Chicago, London: The University of Chicago Press. 